\title{
Implikasi Arus Kas Aktivitas Operasi Terhadap Kinerja Keuangan
}

\author{
Andi Riyanto', Galih Raspati², Yuri Rahayu ${ }^{3}$, Yepi Sopian ${ }^{4}$ \\ ${ }^{1,3}$ Universitas Bina Sarana Informatika \\ e-mail: ${ }^{1}$ andi.iio@bsi.ac.id, ${ }^{3}$ yuri.yru@bsi.ac.id \\ ${ }^{2,4}$ STIE Pasim Sukabumi \\ e-mail: ${ }^{2}$ galih_raspati@yahoo.com, ${ }^{4}$ yepisopian@gmail.com

\begin{tabular}{ccc}
\hline Diterima & Direvisi & Disetujui \\
$06-02-2021$ & $11-03-2021$ & $17-03-2021$ \\
\hline
\end{tabular}

\begin{abstract}
Abstrak - Penelitian ini bertujuan untuk mengetahui secara empiris arus kas dari aktivitas operasi terhadap kinerja keuangan perusahaan. Indikator arus kas dari aktivitas operasi diperoleh dari Return on Assets yang dibandingkan dengan profit perusahaan dalam kurun waktu 2018-2020. Tujuan penelitian ingin mengetahui implikasi arus kas dari aktivitas operasi terhadap kinerja keuangan. Metode penelitian yang digunakan dengan menggunakan metode deskriptif dan asosiatif. Data sekunder berupa laporan keuangan PT. Dame Alam Sejahtera tahun 2018-2020. Berdasarkan hasil temuan, perkembangan arus kas dari aktivitas operasi mengalami fluktuasi dikarenakan perusahaan belum memiliki tata kelola operasional yang baik selain itu arus kas aktivitas operasi secara simultan mempengaruhi kinerja keuangan, terutama pada faktor kewajiban lancar, modal kerja dan laba bersih entitas.
\end{abstract}

Kata Kunci: Arus kas, Aktivitas Operasi, Kinerja Keuangan, Return on Assets

Abstract - This study aims to empirically determine the cash flow from operating activities on the company's financial performance. The cash flow indicator from operating activities is obtained from the Return on Assets which is compared to the company's profit in the 2018-2020 period. The research objective was to determine the implications of cash flow from operating activities on financial performance. The research method used is descriptive and associative methods. Secondary data in the form of financial statements of PT. Dame Alam Sejahtera in 2018-2020. Based on the findings, the development of cash flows from operating activities fluctuates due to the fact that the company does not yet have good operational governance. In addition, cash flow from operating activities simultaneously affects financial performance, especially in the factors of current liabilities, working capital and net income of the entity.

Keywords: Cash Flow, Operating Activities, Financial Performance, Return on Assets

\section{PENDAHULUAN}

Kinerja keuangan adalah indikator kunci pencapaian operasional untuk sebuah perusahaan. Indikator keuangan dapat membantu memeriksa kondisi keuangan perusahaan, itulah sebabnya metrik keuangan sangat penting untuk tata kelola perusahaan. Pengukuran kinerja adalah alat manajemen strategis untuk konseptualisasi dan mengukur kinerja bisnis (Lo \& Liao, 2021) dan organisasi bisnis mengakui pentingnya kinerja keuangan ini (Akisik \& Gal, 2011)

Untuk memposisikan aktivitasnya dengan benar dan banyaknya hubungan dengan organisasi bisnis lain, perusahaan membutuhkan informasi akuntansi yang akurat, lengkap dan tepat waktu yang disediakan oleh laporan keuangan (Trigo, Belfo, \& Estébanez, 2014; Hertati, 2015). Salah satu fungsi laporan keuangan adalah untuk memahami apakah kinerja perusahaan meningkat atau bahkan menurun. Indikator ini bisa terlihat dari arus kas entitas yang diperbandingkan dari beberapa periode akuntansi.
PT. Dame Alam Sejahtera adalah perusahaan jasa pengangkutan, pengumpul dan pemanfaatan limbah B3 (Bahan Berbahaya dan Beracun) yang beralamat di Jl. Raya Siliwangi, Cibadak, Kabupaten Sukabumi. Belakangan ini perusahaan memiliki masalah dari sisi laporan keuangannya, yaitu arus kas tidak berjalan secara efektif. Hal ini terjadi seiring dengan menurunnya arus kas dari aktivitas operasi sehingga berpengaruh pada penurunan kinerja keuangan. Untuk memperjelas permasalahan yang terjadi dapat dilihat dari laporan arus kas aktivitas operasi dan analisa rasio keuangan (Return On Asset) perusahaan pada tabel berikut:

Tabel 1. Perkembangan Arus Kas Aktivitas Operasi dan Kinerja Keuangan PT. Dame Alam Sejahtera

\begin{tabular}{|c|c|c|c|c|}
\hline \multirow{4}{*}{ No } & \multirow{4}{*}{ Bulan } & \multirow{4}{*}{ Tahun } & Arus Kas & \\
\hline & & & Aktivitas & Kinerja \\
\hline & & & $\begin{array}{l}\text { Operasi } \\
\text { (Arus Kas }\end{array}$ & Keuang \\
\hline & & & $\begin{array}{c}\text { Masuk - Arus } \\
\text { Kas Keluar) }\end{array}$ & (ROA) \\
\hline
\end{tabular}




\begin{tabular}{|c|c|c|c|c|}
\hline & & & (Rp.) & $\begin{array}{c}\text { (EBIT/ } \\
\text { Total } \\
\text { Asset }) \\
(\%)\end{array}$ \\
\hline 1 & Januari & 2018 & $32.868 .559,00$ & $2 \%$ \\
\hline 2 & Febuari & 2018 & $9.205 .169,00$ & $10 \%$ \\
\hline 3 & Maret & 2018 & $30.388 .088,13$ & $9 \%$ \\
\hline 4 & April & 2018 & $(5.946 .577)$ & $-2 \%$ \\
\hline 5 & Mei & 2018 & $(4.895 .927,89)$ & $-1 \%$ \\
\hline 6 & Juni & 2018 & $(34.796 .454,67)$ & $-8 \%$ \\
\hline 7 & Juli & 2018 & $110.221 .222,13$ & $20 \%$ \\
\hline 8 & Agustus & 2018 & $\begin{array}{r}(136.590 .824,9 \\
0) \\
\end{array}$ & $-45 \%$ \\
\hline 9 & September & 2018 & $22.520 .813,00$ & $-76 \%$ \\
\hline 10 & Oktober & 2018 & $32.543 .392,00$ & $12 \%$ \\
\hline 11 & November & 2018 & $32.416 .601,22$ & $2 \%$ \\
\hline 12 & Desember & 2018 & $(37.527 .626,34)$ & $4 \%$ \\
\hline 13 & Januari & 2019 & $65.150 .232,52$ & $-3 \%$ \\
\hline 14 & Febuari & 2019 & $(76.769 .921,98)$ & $7 \%$ \\
\hline 15 & Maret & 2019 & $(23.316 .786,90)$ & $3 \%$ \\
\hline 16 & April & 2019 & $22.540 .246,32$ & $-2 \%$ \\
\hline 17 & Mei & 2019 & $(26.593 .966,00)$ & $3 \%$ \\
\hline 18 & Juni & 2019 & $27.675 .637,70$ & $-6 \%$ \\
\hline 19 & Juli & 2019 & $17.178 .141,00$ & $2 \%$ \\
\hline 20 & Agustus & 2019 & $36.846 .483,64$ & $10 \%$ \\
\hline 21 & September & 2019 & $19.178 .917,74$ & $2 \%$ \\
\hline 22 & Oktober & 2019 & $(23.345 .480,88)$ & $-2 \%$ \\
\hline 23 & November & 2019 & $60.737 .441,00$ & $13 \%$ \\
\hline 24 & Desember & 2019 & $(34.090 .402,95)$ & $-3 \%$ \\
\hline 25 & Januari & 2020 & $(30.957 .355,57)$ & $4 \%$ \\
\hline 26 & Febuari & 2020 & $(6.026 .022,51)$ & $4 \%$ \\
\hline 27 & Maret & 2020 & $(10.677 .416,21)$ & $-3 \%$ \\
\hline 28 & April & 2020 & $(44.090 .681,91)$ & $-2 \%$ \\
\hline 29 & Mei & 2020 & $(17.020 .867,26)$ & $4 \%$ \\
\hline 30 & Juni & 2020 & $(4.409 .725,34)$ & $13 \%$ \\
\hline
\end{tabular}

Sumber: Data sekunder yang diolah, 2021.

Berdasarkan tabel 1 terlihat bahwa entitas mengalami siklus fluktuatif dalam kinerja keuangan dengan perhitungan menggunakan Return On Asset (ROA), yakni pada bulan Januari tahun 2018 mencapai sebesar 2\% , Febuari 2018 sebesar 10\% dan Maret 2018 mengalami penurunan dari bulan sebelumnya sebesar 9\%. Pada bulan April 2018 sebesar -2\%, Mei 2018 sebesar -1\% dan bulan Juni 2018 sebesar $-8 \%$ dikarenakan pada bulan tersebut mengalami kenaikan total aset yang tidak diiringi dengan kenaikan profit. Pada bulan Juli 2018 mengalami peningkatan sebesar $20 \%$ dikarenakan pada bulan ini laba perusahaan meningkat, namun pada Agustus 2018 sebesar -45\%, September 2018 sebesar $-76 \%$ mengalami penurunan yang sangat tajam disebabkan pada bulan tersebut mengalami penurunan laba. Bulan Oktober 2018 sebesar 12\%, November 2018 sebesar 2\% dan Desember 2018 sebesar $4 \%$.

Bulan Januari 2019 mengalami penurunan kembali sebesar $-3 \%$ dan mengalami kenaikan pada Febuari 2019 sebesar 7\% dan sebesar 3\% pada Maret 2019. Pada bulan April 2019 terjadi penurunan sebesar $-2 \%$ dan meningkat kembali pada Mei 2019 sebesar 3\%. Bulan Juni 2019 turun menjadi -6\%, Juli 2019 naik sebesar 2\%, Agustus 2019 meningkat signifikan sebesar 10\%. September 2019 turun kembali menjadi $2 \%$, begitupun pada bulan Oktober 2019 turun sebesar-2\%. November 2019 naik sebesar 13\% dan Desember 2019 terjadi penurunan sebesar $3 \%$. Jika dibandingkan pada tahun sebelumnya setiap bulan mengalami kenaikan dan penurunan yang signifikan, sama halnya pada tahun 2018 dikarenakan pada bulan-bulan tersebut mengalami kenaikan total aset yang tidak diiringi dengan kenaikan profit dikarenakan arus kas operasi pada tahun 2018 sampai dengan 2020 tidak berjalan secara efektif tetapi pada tahun 2019 kinerja keuangan perusahaan lebih baik dari tahun 2018.

Pada tahun 2020 kinerja keuangan perusahaan mengalami peningkatan yang cukup baik untuk bulan Januari sebesar 4\%, Februari 4\%, Maret sebesar-3\%, April -2\%, Mei sebesar 4\% dan bulan Juni sebesar $13 \%$.

Hal ini menandakan bahwa perusahaan belum memiliki sistem tata kelola keuangan yang baik sehingga kenaikan total aset tidak sebanding dengan kenaikan laba yang dihasilkan pada bulan Januari 2018 sampai dengan bulan Juni 2020. Artinya perusahaan belum mampu memaksimalkan seluruh asetnya dalam menghasilkan profit sehingga kinerja keuangan perusahaan akan berdampak buruk. Dampak kinerja keuangan buruk ini terjadi dikarenakan banyaknya arus kas negatif atau tidak berjalan sebagaimana mestinya dalam pengelolaan laporan arus kas karena penerimaan lebih kecil sedangkan pengeluaran lebih besar.

Berdasarkan latar belakang yang telah dikemukakan di atas, maka permasalahan dalam penelitian ini dapat diidentifikasikan sebagai berikut: 1) Bagaimana arus kas aktivitas operasi perusahaan; 2) Bagaimana kinerja keuangan perusahaan; dan bagaimana implikasi arus kas dari aktivitas operasi terhadap kinerja keuangan PT. Dame Alam Sejahtera.

Tujuan yang ingin dicapai dalam riset ini untuk mengetahui implikasi arus kas aktivitas operasi terhadap kinerja keuangan perusahaan.

Hasil penelitian terdahulu yang meneliti kinerja keuangan Course and Training Institutions Putra Perwira Sukoharjo tahun 2014-2016 (Supatminingsih \& Setyawati, 2018) menunjukan bahwa arus kas dari aktivitas operasi berdampak terhadap kinerja keuangan perusahaan. Hasil penelitian lainnya pada PT. Hanjaya Mandala Sampoerna memperlihatkan bahwa rasio arus kas bersih terhadap laba bersih hanya memiliki 1 (satu) rasio yang berada dibawah 1 (satu) yaitu pada tahun 2015 yang artinya perusahaan sedang mengalami masalah pada arus kas (Arota, Morasa, \& Wokas, 2019). Hasil analisis perhitungan rasio arus kas operasi PT. Unilever Indonesia menampilkan kalau kinerja keuangan perseroan kurang baik sebab hasil rasio masih dibawah $\mathrm{Rp} 1$ sehingga perseroan tidak sanggup melunasi kewajiban lancarnya hanya dengan memakai arus kas operasi saja serta wajib mencari alternatif lain buat menunjang kas bersih perseroan 
dalam membayar kewajiban lancarnya (Rosmawati \& Hasibuan, 2020).

Arus kas dari aktivitas operasi sangat penting bagi pengambil keputusan yang terkait dengan pembiayaan proyek masa depan dan pembayaran kembali hutang dalam mendukung aktivitas bisnis, meningkatkan profitabilitas dan terkait dengan kebijakan dividen (Noury, Hammami, Ousama, \& Zeitun, 2020).

Arus kas dari aktivitas operasi berasal dari aktivitas penghasil pendapatan utama perusahaan. Arus kas tersebut biasanya berasal dari transaksi dan kejadian lain yang berdampak pada laba rugi (IAI, 2017).

Kian besar jumlah kas yang terdapat dalam entitas memiliki efek yang lebih kecil untuk tidak bisa memenuhi kewajiban finansialnya. Namun hal ini tidak berarti entitas wajib mempertahankan persediaan kas dalam jumlah yang besar karena semakin besar kas menjadikan banyak uang tunai yang mengganggur (idle cash).

Peran kas sangat penting dalam kelangsungan operasional perusahaan, terutama pada kinerja keuangan, sehingga dalam pengelolaannya diperlukan perhatian yang khusus. Kinerja keuangan menggambarkan tentang aktivitas yang kompleks sebab menyangkut daya guna pemanfaatan modal serta efisensi dari aktivitas perusahaan (Kurniati \& Saifi, 2018). Kinerja keuangan perusahaan dapat dibandingkan untuk mengetahui efek terhadap kinerja keuangan dan mengukur kinerja keuangan tersebut adalah dengan analisis rasio dalam hal ini menggunakan rasio keuangan (Irma, 2019; Hidayati \& Selmury, 2021).

Salah satu komponen rasio keuangan yang digunakan adalah Return on Assets (ROA). ROA menunjukkan bagaimana perusahaan menggunakan asetnya untuk mendapatkan laba bersih (Gaspersz, 2012). ROA menjadi sinyal positif yang kredibel bagi investor yang menunjukkan bahwa manajemen perusahaan telah memanfaatkan aset perusahaan yang didanai oleh hutang dan ekuitas (aset = kewajiban + ekuitas) (Marito \& Dewi Sjarif, 2020).

\section{METODE PENELITIAN}

Metode yang digunakan dalam penelitian ini adalah metode deskriptif dan asosiatif karena menjelaskan hubungan antara dua atau lebih variabel. Unit analisis berupa arus kas aktivitas operasi dan kinerja keuangan (ROA) yang diperoleh dari data sekunder yaitu laporan keuangan PT. Dame Alam Sejahtera periode 2018 - 2020 .

Hipotesis yang diajukan sebagai berikut :

Ha : Terdapat implikasi arus kas aktivitas operasi terhadap kinerja keuangan

Ho : Tidak terdapat implikasi arus kas aktivitas operasi terhadap kinerja keuangan
Setelah data penelitian berhasil dikumpulkan, maka langkah berikutnya adalah melakukan analisis data dan interpretasinya. Tujuan dari analisis data dan interpretasi, yaitu menjawab masalah penelitian yang telah dirumuskan pada langkah penelitian sebelumnya, sehingga hasil analisis data dan interpretasinya dapat dijadikan dasar dalam membuat kesimpulan serta rekomendasi bagi pengguna untuk mengambil keputusan bisnis.

Analisis pertama yang dilakukan adalah analisis korelasi Pearson. Analisis korelasi digunakan untuk mengetahui hubungan antara variabel independen dan variabel dependen, apakah mempunyai hubungan yang kuat atau lemah. Korelasi yang digunakan dalam analisis ini yaitu korelasi Pearson Product Moment dengan persamaan sebagai berikut:

$$
\mathrm{r}_{\mathrm{xy}}=\frac{\mathrm{n}(\Sigma \mathrm{xy})-\left(\sum \mathrm{x}\right)\left(\sum \mathrm{y}\right)}{\sqrt{\left\{\left(\mathrm{n} \Sigma \mathrm{x}^{2}-\left(\sum \mathrm{x}\right)^{2}\right\}\left(\mathrm{n} \Sigma \mathrm{y}^{2}-(\Sigma \mathrm{y})^{2}\right)\right.}}
$$

Keterangan:

$\mathrm{r}_{\mathrm{xy}}=$ Koefisien korelasi antara variabel $\mathrm{X}$ dan variabel Y

$\mathrm{n} \quad=$ Jumlah pengamatan

$\mathrm{x}=$ Nilai variabel bebas (arus kas aktivitas operasi)

$\mathrm{y} \quad=$ Nilai variabel terikat (kinerja keuangan)

Penafsiran koefisien korelasi yang ditemukan tinggi atau rendah, maka dapat berpedoman pada ketentuan berikut:

Tabel 2. Pedoman Untuk Memberikan Interprestasi Koefisin Korelasi

\begin{tabular}{ll}
\hline Interval Koefisien & Tingkat Hubungan \\
\hline $0,00-0,199$ & Sangat rendah \\
\hline $0,20-0,399$ & Rendah \\
\hline $0,40-0,599$ & Sedang \\
\hline $0,60-0,799$ & Kuat \\
\hline $0,80-1,000$ & Sangat kuat \\
\hline Sumber : (Sugiyono, 2017)
\end{tabular}

Korelasi dapat menghasilkan angka positif (+) atau negatif (-). Jika korelasi menghasilkan angka positif (+), hubungan kedua variabel bersifat searah. Jika korelasi menghasilkan angka negatif (-), hubungan kedua variabel bersifat tidak searah. Angka korelasi antara 0 sampai dengan 1 , besar kecilnya angka korelasi menentukan kuat atau lemahnya hubungan kedua variabel.

Selanjutnya untuk mengetahui berapa besar persentase dampak arus kas dari aktivitas operasi sebagai variabel $\mathrm{X}$ dan kinerja keuangan sebagai variabel $\mathrm{Y}$ menggunakan analisis koefisien determinasi, dengan persamaan sebagai berikut:

$\mathrm{Kd}=\mathrm{r}^{2} \times 100 \%$

Keterangan: 
$\mathrm{Kd} \quad=$ Koefisien determinasi

$\mathrm{r}^{2} \quad=$ Koefisien korelasi

$100 \%=$ Pengali yang dinyatakan dalam persentase

Analisis regresi diterapkan untuk mengetahui besarnya dampak variabel bebas (X) terhadap variabel terikat $(\mathrm{Y})$. Jika pengukuran dampak ini hanya melihat satu variabel bebas dan satu variabel terikat disebut analisis regresi linear sederhana, dirumuskan sebagai berikut :

$\mathrm{Y}=\mathrm{a}+\mathrm{bX}$

Keterangan:

$\mathrm{Y} \quad=$ Variabel dependen (kinerja keuangan)

$\mathrm{X}=$ Variabel independent (arus kas aktivitas operasi)

a $\quad=$ Konstanta (harga $\mathrm{Y}$ bila $\mathrm{X}=0$ )

$\mathrm{b}=$ Koefisien regresi variabel independent

\section{HASIL DAN PEMBAHASAN}

Hasil analisis korelasi pearson disajikan sebagai berikut :

Tabel 3. Hasil Analisis Korelasi Pearson

\begin{tabular}{|c|c|c|c|}
\hline \multicolumn{4}{|c|}{ Correlations } \\
\hline & & $\begin{array}{c}\text { Arus Kas } \\
\text { Aktivitas } \\
\text { Operasi }\end{array}$ & $\begin{array}{l}\text { Kinerja } \\
\text { Keuangan }\end{array}$ \\
\hline \multirow{3}{*}{$\begin{array}{l}\text { Arus Kas } \\
\text { Aktivitas } \\
\text { Operasi }\end{array}$} & $\begin{array}{l}\text { Pearson } \\
\text { Correlation }\end{array}$ & 1 &, $457^{*}$ \\
\hline & Sig. (2-tailed) & & ,011 \\
\hline & $\mathrm{N}$ & 30 & 30 \\
\hline \multirow{3}{*}{$\begin{array}{l}\text { Kinerja } \\
\text { Keuangan }\end{array}$} & $\begin{array}{l}\text { Pearson } \\
\text { Correlation }\end{array}$ &, $457^{*}$ & 1 \\
\hline & Sig. (2-tailed) & ,011 & \\
\hline & $\mathrm{N}$ & 30 & 30 \\
\hline
\end{tabular}

Sumber: Data sekunder yang diolah, 2021.

Berdasarkan tabel 3, diperoleh angka korelasi $\mathrm{R}=0,457$. Jika dilihat dari interval korelasi, maka posisi $\mathrm{R}$ pada interval 0,40 - 0,599 yang artinya hubungan kedua variabel adalah sedang. Dikarenakan angka (sig) $0,011<0,05$ maka menunjukan hubungan arus kas aktivitas operasi terhadap kinerja keuangan signifikan. Artinya arus kas dari aktivitas operasi dapat mempengaruhi komponen kinerja keuangan, terutama mempengaruhi kewajiban lancar, pengeluaran modal kerja dan laba bersih entitas (Ngala, Manoppo, \& Mangindaan, 2020). Berdasarkan indikator korelasi Pearson, tingkat arus kas dari aktivitas operasi menunjukkan hasil yang baik, untuk itu entitas harus dapat mempertahankan atau jika perlu meningkatkan aktivitas operasi dari arus kas pada periode yang akan datang agar kinerja keuangan dapat meningkat dengan signifikan.
Besarnya persentase pengaruh arus kas aktivitas operasi terhadap kinerja keuangan ditunjukan oleh nilai koefisien determinasi, dimana dalam tabel 3 memiliki nilai 0,457, maka koefisien determinasi dapat dihitung sebagai berikut:

$$
\begin{aligned}
\mathrm{Kd} & =\mathrm{r}^{2} \times 100 \% \\
& =0,457 \times 100 \% \\
& =0,208 \times 100 \% \\
& =20,8 \%
\end{aligned}
$$

Artinya besarnya dampak arus kas aktivitas operasi terhadap kinerja keuangan pada PT. Dame Alam Sejahtera sebesar 20,8\% dan sisanya 79,2\% di pengaruhi oleh faktor lain yang ada pada pos-pos laporan keuangan lainnya.

Hasil analisis regresi linier sederhana disajikan sebagai berikut :

Tabel 4. Hasil Analisis Regresi Linier Sederhana

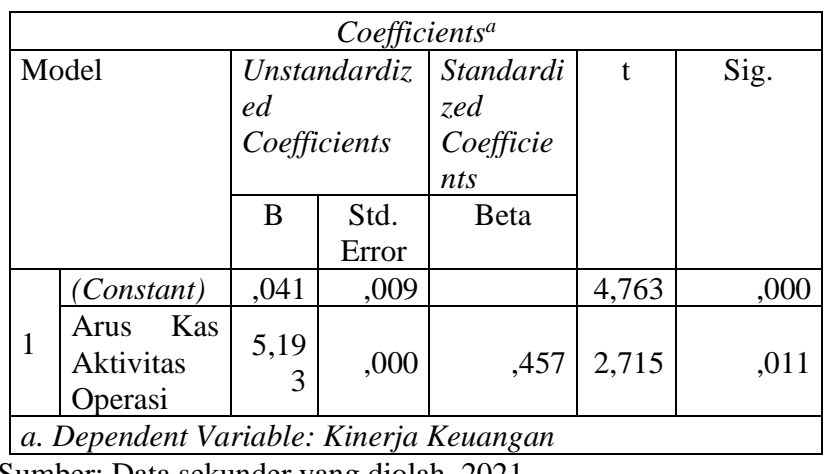
Sumber: Data sekunder yang diolah, 2021.

Berdasarkan tabel 4 dapat diketahui nilai constant (a) sebesar 0,041, sedangkan nilai arus kas aktivitas operasi (koefisien regresi) sebesar 5,193 sehingga persamaan regresinya dapat ditulis:

$\mathrm{Y}=\mathrm{a}+\mathrm{bX}$

$\mathrm{Y}=0,041+5,193 \mathrm{X}$

Persamaan tersebut dapat diterjemahkan sebagai berikut :

1) Angka konstanta sebesar 0,041 mengandung arti bahwa nilai konsisten variabel kinerja keuangan sebesar 0,041.

2) Koefisien regresi $X$ sebesar 5,193 menyatakan bahwa setiap penambahan $1 \%$ nilai arus kas aktivitas operasi, maka nilai kinerja keuangan bertambah sebesar 5,193. Koefisien regresi tersebut bernilai positif sehingga dikatakan bahwa arah dampak variabel $\mathrm{X}$ terhadap $\mathrm{Y}$ adalah positif.

Berdasarkan resume analisis regresi linier sederhana, untuk meningkatkan kinerja keuangan maka entitas perlu meningkatkan pula arus kas dari aktivitas operasi. Kinerja keuangan yang stabil sangat dipengaruhi oleh arus kas dari aktivitas operasi (Nurjanah \& Pratiwi, 2020). 


\section{KESIMPULAN}

Berdasarkan hasil dan pembahasan penelitian maka dapat disimpulkan perkembangan arus kas aktivitas operasi dari tahun 2018 sampai dengan tahun 2020 mengalami fluktuasi, hal ini diakibatkan oleh penerimaan kas yang dihasilkan lebih kecil dibandingkan dengan pengeluaran kas, hal ini disebabkan penerimaan kas yang dihasilkan dari aktivitas operasi berkurang. Untuk kinerja keuangan PT. Dame Alam Sejahtera mengalami fluktuasi setiap bulannya dengan menggunakan analisis ROA (Return on Asset). Artinya perusahaan belum memiliki sistem tata kelola perusahaan yang baik karena kenaikan total aset tidak sebanding dengan kenaikan laba sehingga kinerja keuangan berdampak negatif atau menurun. Hasil uji hipotesis didapatkan adanya implikasi arus kas aktivitas operasi terhadap kinerja keuangan. Arus kas dari aktivitas operasi sangat mempengaruhi kinerja keuangan, terutama pada faktor kewajiban lancar, modal kerja dan laba bersih.

Saran yang dapat diberikan untuk perusahaan diharapkan dapat mengelola arus kas aktivitas operasi dengan efektif. Arus kas kegiatan operasi senantiasa memperoleh atensi yang lebih dari manajemen perusahaan, sebab arus kas kegiatan operasi menggambarkan jiwa (lifeblood) untuk suatu industri serta sangat fundamental atas eksistensinya. Perusahaan harus dengan tepat menentukan kebijakan dalam pengalokasian sumber dan penggunaan kas untuk menjaga kinerja keuangan perusahaan. Rekomendasi untuk penelitian selanjutnya diharapkan mampu mengatasi keterbatasan studi, dengan cara inklusi pada lebih banyak variabel keuangan dan dengan jangka waktu atau periode keuangan yang lebih lama.

\section{REFERENSI}

Akisik, O., \& Gal, G. (2011). Sustainability in businesses, corporate social responsibility, and accounting standards: An empirical study. International Journal of Accounting and Information Management, 19(3), 304-324. https://doi.org/10.1108/18347641111169287

Arota, P. S., Morasa, J., \& Wokas, H. N. (2019). Analisis Rasio Arus Kas untuk Menilai Kinerja Keuangan pada PT. Hanjaya Mandala Sampoerna Tbk 2014-2018. Jurnal EMBA: Jurnal Riset Ekonomi, Manajemen, Bisnis Dan Akuntansi, 7(3).

Gaspersz, V. (2012). All-in-one Finance for Non-
Financial Managers. Bogor: Vinchristo.

Hertati, L. (2015). Competence of Human Resources, The Benefits of Information Technology on Value of Financial Reporting in Indonesia. Research Journal of Finance and Accounting, 6(8), 12-18.

Hidayati, C., \& Selmury, N. (2021). Analisis Rasio Keuangan dan Analisis Eva Sebagai Alat untuk Menilai Kinerja Keuangan PT CHAROENPOKPHAND INDONESIA TBK yang Terdaftar Dibursa Efek Indonesia. JURNAL EKBIS, 21(1), 16-23. https://doi.org/https://doi.org/10.30736/ekbis.v $17 \mathrm{i} 1$

Indonesia, I. A. (2017). Pernyataan Standar Akuntansi Keuangan (PSAK) No. 02: Laporan Arus Kas. Jakarta: Ikatan Akuntan Indonesia.

Irma, A. D. A. (2019). Pengaruh Komisaris, Komite Audit, Struktur Kepemilikan, Size, Dan Leverage Terhadap Kinerja Keuangan Perusahaan Properti, Perumahan Dan Konstruksi 2013-2017. Jurnal Ilmu Manajemen, 7(3), 697-712.

Kurniati, R. A., \& Saifi, M. (2018). Pengaruh Employee Stock Ownership Program (ESOP) Dan Leverage Terhadap Kinerja Keuangan (Studi pada Perusahaan Sektor Perbankan yang Terdaftar Di Bursa Efek Indonesia Tahun 20142016). Jurnal Administrasi Bisnis, 62(2), 150157.

Lo, F. Y., \& Liao, P. C. (2021). Rethinking financial performance and corporate sustainability: Perspectives on resources and strategies. Technological Forecasting and Social Change, 162.

https://doi.org/10.1016/j.techfore.2020.120346

Marito, B. C., \& Dewi Sjarif, A. (2020). The Impact of Current Ratio, Debt to Equity Ratio, Return on Assets, Dividend Yield, and Market Capitalization on Stock Return (Evidence from Listed Manufacturing Companies in Indonesia Stock Exchange). Economics, 7(1), 10-16. https://doi.org/10.27512/sjppiukm/ses/a11052020

Ngala, K. U., Manoppo, W. S., \& Mangindaan, J. V. (2020). Analisis Laporan Arus Kas pada PT. United Tractors, Tbk. Productivity, 1(4), 301305. 
Noury, B., Hammami, H., Ousama, A. A., \& Zeitun, R. (2020). The prediction of future cash flows based on operating cash flows, earnings and accruals in the French context. Journal of Behavioral and Experimental Finance, 28, 100414.

https://doi.org/10.1016/j.jbef.2020.100414

Nurjanah, \& Pratiwi, A. (2020). Analisis Laporan Arus Kas Operasi Untuk Menilai Kinerja Keuangan Pada PT. Gudang Garam TBK. Procuratio: Jurnal Ilmiah Manajemen, 8(2), 140-146.

Rosmawati, S., \& Hasibuan, R. H. (2020). Analisis Laporan Arus Kas Dalam Menilai Kinerja Keuangan Pada PT. Unilever Indonesia, Tbk. CITRA EKONOMI, 1(1).
Sugiyono. (2017). Metode Penelitian Kuantitatif Kualitatif dan $R \& D$. Bandung: Alfabeta.

Supatminingsih, S., \& Setyawati. (2018). An Analysis Of Cash Flow Report Effect On Financial Performance (Case Study In Course And Training Institutions Putra Perwira Sukoharjo 2014-2016). International Journal of Economics, Business and Accounting Research (IJEBAR), 2(01), 8-18.

Trigo, A., Belfo, F., \& Estébanez, R. P. (2014). Accounting Information Systems: The Challenge of the Real-time Reporting. Procedia Technology, 16, 118-127. https://doi.org/10.1016/j.protcy.2014.10.075 